NBER WORKING PAPER SERIES

\title{
SUSTAINABILITY OF PERSISTENT \\ CURRENT ACCOUNT DEFICITS
}

\author{
Gian Maria Milesi-Ferretti \\ Assaf Razin
}

Working Paper 5467

\author{
NATIONAL BUREAU OF ECONOMIC RESEARCH \\ 1050 Massachusetts Avenue \\ Cambridge, MA 02138 \\ February 1996
}

This paper was prepared for the conference on "Implications of International Capital Flows for Macroeconomic and Financial Policy," held in Washington on December 12-13, 1995. We are grateful to Tam Bayoumi, Eduardo Borensztein, Susan Collins, Enrica Detragiache, Stan Fischer, Karen Lewis, Paul Masson, Peter Montiel, Michael Mussa, Jonathan Ostry, Dani Rodrik, Jorge Roldós, Julio Santaella, Miguel Savastano, and Larry Summers for useful discussions and suggestions. This paper is part of NBER's research program in International Finance and Macroeconomics. Any opinions expressed are those of the authors and not those of the International Monetary Fund, or the National Bureau of Economic Research.

(C) 1996 by Gian Maria Milesi-Ferretti and Assaf Razin. All rights reserved. Short sections of text, not to exceed two paragraphs, may be quoted without explicit permission provided that full credit, including $(\odot$ notice, is given to the source. 


\title{
SUSTAINABILITY OF PERSISTENT \\ CURRENT ACCOUNT DEFICITS
}

\begin{abstract}
This paper puts forward a notion of current account sustainability that explicitly takes into account willingness to pay and willingness to lend in addition to intertemporal solvency. It argues that this notion of sustainability provides a better framework for understanding the variety of country experiences with protracted current account imbalances. Based on this notion, we identify a number of operational indicators related to the structure of the economy, the economic policy stance, and political economy factors. We use these sustainability indicators to evaluate the experience of a number of countries that ran persistent current account imbalances, and derive policy implications consistent with our notion of sustainability.
\end{abstract}

Gian Maria Milesi-Ferretti

International Monetary Fund

700 19th Street, NW

Washington, DC 20431
Assaf Razin

Fiscal Affairs Department International Monetary Fund 700 19th Street, NW Washington, DC 20431 and NBER 


\section{INTRODUCTION}

What persistent level of current account deficits should be considered sustainable? Conventional wisdom is that current account deficits above 5\% of GDP flash a red light, in particular if the deficit is financed with short- term debt or foreign exchange reserves, and if it reflects high consumption spending. How seriously should these, or any, specific thresholds be taken? Which other factors should one consider when evaluating sustained current account imbalances? A cursory look at historical episodes suggests that a number of countries, such as Australia, Ireland, Israel, and South Korea, were able to sustain persistent current account deficits close to this threshold for several years, while others, such as Chile and Mexico, suffered severe external crises.

The natural question that comes to mind in evaluating the viability of external imbalances is whether the country is solvent; that is, whether it has the ability to generate sufficient trade surpluses in the future to repay existing debt. We argue in this paper that this notion of solvency, which is satisfied when the country meets its intertemporal budget constraint, is not always the appropriate yardstick for evaluating the sustainability of external imbalances. First, it considers only the ability to pay, but abstracts from the willingness to pay. The present value of trade surpluses may theoretically be sufficient to repay the country's external debt, but it may not be politically feasible to divert output from domestic to external use in order to service the debt. Second, this notion of solvency often relies on the assumption that foreign investors are willing to lend to the country on current terms. This assumption, however, may be unrealistic, in particular when there is uncertainty about the country's willingness to meet its debt obligations. Clearly, availability of foreign funds, together with other market imperfections, imposes constraints on the sustainability of current account imbalances in addition to those imposed by pure intertemporal solvency.

In this paper we argue that a notion of current account sustainability that explicitly takes into account willingness to pay and willingness to lend in addition to intertemporal solvency analysis provides a better framework for understanding the variety of country experiences with protracted current account imbalances. We use this notion in the study of a selected number of countries, with the purpose of identifying the major determinants of current account sustainability. Some of these countries experienced an external crisis, while others were able to sustain persistent current account imbalances. In addition to the burden of external debt service (adjusted for growth and real exchange rate changes), we find that among the most important operational indicators of current account sustainability are the size of the export sector and the level of international competitiveness, the level of domestic savings, the composition of external liabilities, the strength of the financial system, and the degree of political stability. In addition, fiscal consolidation is often a key feature of the adjustment required to generate trade surpluses. 
The rest of the paper is organized as follows. Section II discusses alternative notions of sustainability of current account imbalances. Section III develops the notion of intertemporal solvency, which links current account imbalances with intertemporal consumption and investment decisions, using simple relations derived from national accounting identities. Section IV examines key determinants of willingness to pay and to lend in the context of a simple model of international portfolio allocation and moral hazard. Section V develops a set of operational indicators of sustainability, based on the theoretical analysis of the previous sections. We relate actual country experiences to the theoretical discussion in Section VI, where we try to distill some policy lessons: Section VII concludes. A companion paper (Milesi-Ferretti and Razin (1995)) develops the analytical structure and provides the analysis of country episodes.

\section{NOTIONS OF SUSTAINABILITY}

The current account deficit (or surplus) is the positive (negative) increment to the stock of external liabilities of the economy. An evaluation of persistent current account imbalances has to take into account their contribution to the build-up of this stock. Three related questions are frequently asked in relation with an economy's external imbalances: is a debtor country solvent ? Are current account imbalances sustainable ? Is the current account deficit excessive ? We focus on the first two questions, and discuss briefly the third.

\section{1 Solvency and sustainability}

Solvency is theoretically defined in relation to an economy's present val'se budget constraint. In this sense, an economy is solvent if the present discounted value of future trade surpluses equals current external indebtedness. In the case of public finances, solvency implies that the present discounted value of future budget surpluses is equal to the current public debt. The practical applicability of the theoretical definition is hampered by the fact that it relies on future events/policy decisions without imposing any "structure" on them. For example, in the case of fiscal imbalances, if future surpluses are sufficiently large virtually any deficit path can be consistent with intertemporal solvency. Therefore researchers have attempted to define a baseline for future policy actions. In the case of public sector solvency this has typically been done by postulating a continuation into the indefinite future of the current policy stance and no change in the relevant features of the macroeconomic environment. $1 /$ This gives rise to the notion of "sustainability" - the current policy

1/ See, for example, Corsetti and Roubini (1991). 
stance is "sustainable" if its continuation in the indefinite future does not violate solvency (budget) constraints.

The definition of sustainaibility based on solvency considerations is simpler for riscal imbalances, given that these can be associated (at least to some degree) with direct policy decisions on taxation and government expenditure. Defining sustainability is more complex in the case of current account imbalances, given that these reflect the interaction between savings and investment decisions of the government and domestic private agents, as well as the lending decisions of foreign investors. While government decisions can, to a first approximation, be taken as given, this is not the case for private sector decisions. Furthermore, a key relative price -- the exchange rate -- is a forward-looking variable that by definition depends on the future evolution of policy variables.

An alternative way of formulating the question of whether current account imbalances are sustainable is the following. Is a continuation of the current policy stance and/or of the present private sector behavior going to entail the need for a "drastic" policy shift (such as, for example, a sudden policy tightening causing a large recession), or to lead to a "crisis" (such as, for example, an exchange rate collapse leading to an inability to service external obligations) ? If the answer is y'es, we have a case of unsustainability. This drastic change in policy or crisis situation can be triggered by a domestic or an external shock, that causes a shift in domestic and foreign investors' confidence and a reversal of international capital flows.1/ Note that the shift in foreign investors' confidence may relate to their perception of a country's inability or unwillingness to meet its external obligations.

There exists an issue concerning the "trigger" that will give rise to the policy reversal. The evaluation of a policy scenario based on a model that incorporates the expectations of forward-looking private agents needs a specification of the "event" that will trigger a policy shift. For example, this event could be a given combination of a level of the external debt to GDP ratio and the realization of a negative shock. Evidently, private agents' behavior and its implications for the future path of the economy will depend on the particular "trigger". The event that would trigger a policy shift is in principle different across countries, and may reflect different degrees of vulnerability to external shocks, or a difference in the capacity to undertake adjustment policies. For example, the degree of diversification of the export base makes a country more or less vulnerable to terms of trade shocks,

$1 /$ In the presence of uncertainty, definition of solvency and sustainability rely to some degree on expected values, implying that in some states of the world insolvency will occur. Under these circumstances, the issue becomes how likely the occurrence of a "bad" scenario is, and how vulnerable is a country to external shocks (which depends, among other things, on the expected distribution of the shock). 
while the political-economic situation affects the ability of the government to implement drastic changes in policy without causing social and political upheaval. 1 /

\section{II.2 "Excessive" current account imbalances}

The question whether given current account balances are "excessive" can be answered only in the context of a model that yields predictions about the "equilibrium" path of external imbalances. Actual imbalances can then be compared to the theoretically predicted ones in order to judge whether they have been excessive or not. For example, a benchmark for defining excessive deficits can be based on a representative agent model, with consumption behavior determined according to the permanent income hypothesis, in the presence of free capital mobility and investment adjustment costs.

Two main approaches to the empirical implementation of this model have been used. The first approach (see Leiderman and Razin (1991). Glick and Rogoff (1995) and Razin (1995)) relies on structural estimation of the model, and focuses in particular on estimated responses to various types of shocks (permanent and transitory, country-specific and global). The estimated responses can be used to evaluate the persistence of current account imbalances. The second approach (see; for example, Ghosh and Ostry (1995)) uses vector autoregression analysis to estimate the consumption-smoothing current account, which is equal to minus the present discounted value of expected changes in national cash flow (i.e., outpuc minus investment minus government spending). The predicted current account behavior is then used as a benchmark to evaluate "excessive" current account imbalances.

The three concepts of solvency, sustainability and "excessive" current account deficits imply an increasing order of restrictiveness. The first concept, based on the intertemporal budget constraint, can accommodate a variety of future behavior patterns. The second is based on a continuation of the current policy stance, and therefore imposes more structure on future behavior. Within the notion of sustainability, we can also include cases in which a timely reversal of the current policy stance is sufficient to prevent a "hard landing". The notion of "excessive" current account deficits is instead based on deviations from an "optimal" benchmark, derived under the assumption of perfect capital mobility and efficient financial markets.

1/ Another implication is that the probability private agents attribute to a policy shift is state-contingent, and can be taken to be a measure of sustainability. For a more thorough discussion of this issue, see, for example, Horne (1991). A different notion of sustainability was put forward by Krugman in the context of the dollar overvaluation in the mid-eighties (Krugman (1985)). He extrapolated the future path of the exchange rate using interest rate parity and evaluated at this exchange rate the implied future path of the US current account balance. Having found an explosive path of US external liabilities, he concluded that the level of the dollar (and the market fo:ecasts of its future path) was unsustainable. 


\section{INTERTEMPORAL SOLVENCY}

In this Section we use standard accounting identities to present the notion of intertemporal solvency, emphasizing in particular the role of growth, interest rates and the real exchange rate.

We define intertemporal solvency as a situation in which the country as a whole, and each economic unit within the country, including the government, obey their respective intertemporal budget constraints. In the context of the overall economy's resource constraint, the current account clearly plays a crucial role, since it measures the change in the net foreign asset position of the country. $1 /$

Assume that the domestic economy grows at a given rate $\gamma<r \underline{2 /}$ let $s_{t}, p_{t}, p^{*}$ and $i_{t}^{*}$ be the nominal exchange rate, the domestic GDP deflator, the foreign GDP deflator, and the world nominal interest rate, respectively, and define the real exchange rate $q_{t}$ as $p_{t} / s p^{*}{ }_{r}$. We can then rewrite the current account identity (1) as follows:

$$
s_{t} F^{*} F_{t}-s_{t} p_{t-1}^{*} F_{t-1}=p_{t}\left(Y_{t}-C_{t}-G_{t}-I_{t}\right)+i^{*} s_{t} p_{t-1}^{*} F_{t-1}
$$

where $F_{t}$ is the stock of foreign assets denominated in foreign goods, $\mathrm{Y}$ is GDP, $\mathrm{C}$ is private consumption, $G$ is government current expenditure and $I$ is total investment (private and public). Equation (1) can be rearranged so that the current account balance is also made equal to the difference between the economy's total savings and total investment. $\underline{3}$ / Let the foreign assets-to- output ratio $f_{t}$ be equal to $F_{t-1} / q_{t} Y_{t}$. Dividing both sides of (4) by nominal GDP, $\mathrm{p}_{t} \mathrm{Y}_{t}$, and re-arranging terms, we obtain:

$$
f_{t+1}-f_{t}=\frac{1}{\left(1+\gamma_{t}\right)\left(1+\epsilon_{t}\right)}\left[t b_{t}+f_{t}\left(r^{*}-\epsilon_{t}-\gamma_{t}-\gamma_{t}\right)\right]
$$

where $f_{t}=F_{t-1} / Y_{t}$, other lower-case letters indicate the ratio of the respective variables to GDP, and $\epsilon$ is the rate of real appreciation of the domestic currency. This expression simply says that changes in the ratio of foreign assets to GDP are driven by trade imbalances and by a "debt dynamics" term

\footnotetext{
1/ See Obstfeld and Rogoff (1995) for a comprehensive analysis of intertemporal solvency.

2/ Otherwise a country could play "Ponzi games" indefinitely -- that is, borrowing to repay interest on its outstanding debt, without violating solvency conditions, as long as total indebtedness rises at a rate below the economy's growth rate. This possibility, which can arise in a Samuelson-type overlapping generations model (see Gale (1973)), implies that the economy follows a dynamically inefficient growth path.

3/ Equation (1) also shows that the ratio of current account imbalances to domestic GDP is not invariant to the world inflation rate, analogously to the measure of the domestic budget deficit (inclusive of interest payments) in the presence of domestic inflation. A more precise measure of the current account would neod to account for the fact that with positive world inflation and foreign assets (liabilities) denominated in nominal terms part of the measured current account imbalances reflect anticipated repayment of principal.
} 
proportional to $f\left(r^{*}-\gamma-\epsilon\right)$. $1 /$ This latter term rises with the world rate of interest and falls with the rate of real exchange rate appreciation and the rate of growth of the domestic economy.

Consider now an economy in steady state, in which consumption, investment, public expenditure and the stock of foreign assets (liabilities) are constant as a fraction of GDP. What is the long-run net resource transfer (trade surplus) that an indebted country must undertake in order to keep the debt to output ratio constant? From equation (2), we get

$$
t b=1-i-c-g=-f\left(r^{*}-\epsilon-\gamma\right)
$$

where $t b$ is the long-run trade balance. This expression highlights the role played by the average future value of world interest rates, domestic growth and the long-run trend in the real exchange rate in determining the resource transfers necessary to keep the debt to GDP ratio from increasing. 2 / Consider the case in which the long-run real exchange rate is constant $(\epsilon=0)$. Condition (3) then indicates that the country's long-run absorption can be higher than its income only if the country is a net creditor. In this case the country will run a trade deficit, equal to $(r-\gamma) f$, but a current account surplus equal to $\gamma f$, thanks to the interest it earns on its foreign assets. In other words, in the presence of economic growth permanent current account deficits can be consistent with solvency even when the growth rate is below the world interest rate, provided they are accompanied by sufficiently large trade surpluses.

Clearly, if the long-run growth rate of the economy is zero, the current account must be balanced in order for the foreign debt (assets) to GDP ratio to be constant. In this case, a country that is a debtor in the long run will have to run a trade surplus, equal to - $f$, to pay the interest on its external liabilities, while a country that is a long-run creditor will run a trade deficit.

In the long run, the dynamics of the real exchange rate can be assumed to be driven by the evolution of productivity differentials between the traded and nontraded goods in the domestic economy and in the rest of the world (the Balassa-Samuelson effect). Define $d$ as the (log of the) relative price of traded goods across countries, and $\mathrm{a}^{\mathrm{T}}\left(\mathrm{a}^{\mathrm{N}}\right)$ as (the $\log$ of) the productivity level in the traded (nontraded) sector. It can be shown that the changes in the real exchange rate are determined as follows:

1/ We ignore the term $\gamma \epsilon$, which is a discrete time residual.

2/ Cohen (1995) considers the Mexican resource transfers (as a fraction of GDP) after the 1982 debt crisis as an "upper bound" on the feasible resource transfers for heavily indebted countries. He then compares this magnitude with the equivalent of equation (3) for other highly indebted countries, in order to assess their solvency prospects. 


$$
\epsilon=\dot{d}+(1-\beta)\left[\frac{v}{\alpha}\left(a_{T}-a_{T}^{*}\right)-\left(a_{N}-a_{N}^{*}\right)\right]
$$

where a star indicates "foreign" variables, $\alpha(v)$ is the labor share in the traded (nontraded) goods sector and $\beta$ is the share of traded goods in the price index used for the calculation of the real exchange rate. $1 /$ For given behavior of productivity in the nontraded good sectors, countries with more rapid productivity increases in the traded goods sector than its trading partners will, ceteris paribus, experience a real exchange rate appreciation and therefore can sustain a larger debt to output ratio.

\section{WILLINGNESS TO PAY AND WILLINGNESS TO LEND}

In this section we focus on the factors that determine international investors' willingness to lend to a given country. To highlight this issue in a simple way, we present a simple (static) model of international portfolio diversification with moral hazard. An international investor has to decide its optimal portfolio allocation by choosing investment projects across $\mathrm{J}+1$ countries, indexed by $\mathrm{j}$. The rate of return in the home country $(j=H)$ expressed in foreign currency follows an i.i.d. process with mean $\rho_{\mathrm{H}}$ and variance $\sigma_{\mathrm{H}}^{2}$. The remaining $\mathrm{J}$ countries (the rest of the world) are symmetric and have rates of return $r^{j}$, which follow a random i.i.d. process with mean $\rho$ and variance $\sigma^{2}$.

Assume that the international investor has a portfolio of size $W$, and denote by $\theta$ the share of the investor's portfolio allocated to the home country. Her/his portfolio's expected return is given by:

$$
\begin{gathered}
W\left[\theta \rho_{H}+(1-\theta) \rho\right] \\
\rho_{H}=i_{H}-\frac{s}{s}
\end{gathered}
$$

and the variance is given by

1/ See, for example, Frenkel and Razin (1996). The coefficients $\alpha, \beta$ and $v$ are assumed for simplicity to be equal across countries. Traded goods are typically industrial and agricultural products, as well as some services (such as travel), while nontraded goods comprise construction and other services, including government services. A terms of trade shock would affect the level of $d$. 


$$
W^{2}\left(\theta^{2} \sigma_{H}^{2}+\frac{(1-\theta)^{2}}{J} \sigma^{2}\right)
$$

where $i_{H}$ is the rate of return in the home country's currency, $\mathrm{s}$ is the exchange rate between the home country and the rest of the world and a dot indicates a time derivative. The variance on the rate of return $\sigma_{\mathrm{H}}^{2}$ represents the combined effect of exchange rate risk and domestic interest rate risk. Clearly, both $\rho_{\mathrm{H}}$ and $\sigma_{\mathrm{H}}^{2}$ are endogenous, since they depend on the government's policy choices. This endogeneity is made explicit below (see equation (8)). The international investor is assumed to have constant absolute risk aversion, with a coefficient $\gamma$. Thus, expected utility $U$ is given by:

$$
U=W\left[\theta \rho_{H}+(1-\theta) \rho\right]-\frac{\gamma W^{2}}{2}\left[\theta^{2} \sigma_{H}^{2}+\frac{(1-\theta)^{2}}{J} \sigma^{2}\right]
$$

Maximizing expected utility with respect to $\theta$ and denoting the foreign currency value of home country's indebtedness $\theta \mathrm{W}$ by $\mathrm{B}_{\mathrm{H}}$ we obtain:

$$
B_{H}=\left(\sigma_{H}^{2}+\frac{\sigma^{2}}{J}\right)^{-1}\left[\frac{i_{H}-s / s-\rho}{\gamma}+W \frac{\sigma^{2}}{J}\right]
$$

Figure 1 depicts the supply of external finance $B_{H}$ as a function of the mean rate of return in the home country $\rho_{H}$, which will be identified as the cost of foreign borrowing. From equation (9) one can verify that the supply schedule is upward-sloping; that is, the country has to raise the rate of interest (adjusted for expected exchange rate changes) in order to elicit more capital from abroad. Furthermore, the supply schedule shifts upwards as: i) the opportunities for international diversification (J) rise (as in the case of "emerging markets"); ii) the country's credit and exchange rate risk $\left(\sigma_{\mathrm{H}}^{2}\right)$ increases; iii) the rate of interest in the rest of the world $(\rho)$ increases. It shifts downwards as iv) the riskiness of the rest of the world's investment projects ( $\sigma$ ) rises and $v$ ) the size of the world's portfolio $(W)$ increases. $1 /$

\section{[FIGURE 1 ABOUT HERE]}

As highlighted in Figure 1, at the given level of external liabilities $B_{H}$, in order to elicit external funding a country must pay the rate of interest $\rho_{H}$ which is determined as the intersection between the supply-of-external-funds schedule and the vertical line originating at $B_{H}$. If a "bad" shock that shifts the supply schedule upwards occurs, there will be an increase in the country's cost of external

1/ As shown in Calvo (1995) and Calvo and Mendoza (1995), small "news" about the mean retum of the investment project in the home country can have a large effect on the share of world portfolio allocated to the home country, provided that the portfolio is well diversified ( $\mathrm{J}$ is large). 
borrowing $\rho_{\mathrm{H}}$. This increase may force the country to drastically change its policy stance in order to generate the additional flow of resources necessary to service external liabilities.1/

So far we have focused on the relation between international investors' willingness to lend and the risk and return characteristics on their investment. We now briefly consider willingness to pay by the borrower, assuming that she is better informed about the riskiness of its projects than the international investor. As shown in Stiglitz and Weiss (1981) in the context of bank lending, this informational structure can lead to credit rationing. The fundamental factor is that the rate of interest a bank charges may itself affect the riskiness of loans by affecting the action of borrowers (moral hazard or incentive effect).

A country that borrows an amount $B_{H}$, expressed in foreign currency, at the rate of interest $r_{H}$ will have an incentive to default on its loan if the real return on its project $Y$ plus the real collateral $C$ are insufficient to repay the promised amount, $s / p B_{H}\left(1+r_{H}\right)$, where $p$ is the domestic price level, so that $s / p$ is the real exchange rate. In a strict sense, collateral can be identified with the "equity" of the country in the project. Alternatively, it could be interpreted as loan guarantees or as those country assets that can be seized by the lender in the event of a default. In a more general sense, it could include the present value of the cost of penalties imposed on a defaulting country, such as trade disruptions and isolation from international capital markets, and the "reputation cost" associated with default.

Investors' perception of the policy instruments the government will use to meet external obligations is influenced by political economy considerations. For example, capital flight driven by fear of direct taxation or exchange rate depreciation can increase external debt, $B$, beyond the accumulated level of past current account imbalances.2/ The existence of implicit or explicit bailout clauses can worsen moral hazard problems, analogously to a decline in collateral. In practice, the international financial community may be unwilling to let a country default on its debt obligations, because of the trade and capital markets disruptions this could induce or for protection of foreign investors by their governments. Moral hazard problems may be exacerbated by the implicit or explicit bailout clauses

1/ Equation (8) can be re-arranged to yield a risk premium-adjusted interest rate parity condition as a function of the deviation of the portfolio share of the home country $\theta$ from the minimum variance portfolio share $\theta_{\min }$. The risk premium is exogenous in this model, and the home country's share of the world portfolio adjusts so as to ensure that (8) holds. A more complete model would endogenize the domestic rate of return and its variance, the rate of depreciation and hence the risk premium.

2/ In this case, $B$ represents gross external imbalances for the country as a whole. However, the virtual impossibility to tax foreign assets held abroad by domestic residents make this the relevant measure of debt. 
within a debtor country: for example, excessive borrowing by the banking sector can be induced by expectations of a government bailout should the sector run into financial difficulties.

Clearly, moral hazard problems have an impact on international investors' willingness to lend. For example, it can be shown that when the interest rate charged on international loans increases, the borrower has an incentive to undertake riskier projects, thereby further increasing the probability of default. $1 /$ This implies that the supply of funds curve depicted in Figure 1 will be steeper in the presence of moral hazard problems; it could even become backward-bending. leading to credit rationing.

\section{OPERATIONAL INDICATORS OF SUSTAINABILITY}

This section discusses possible operational indicators of current account sustainability, based the analysis of solvency and willingness to lend considerations identified in Sections III and IV, respectively. We focus in particular on the economy's structure, macroeconomic policy, and political economy factors, and link them with the evolution of external imbalances.

\section{V.I Structural features}

i) Investment/savings. The current account balance is determined by the difference between national savings and domestic investment. For a given current account balance, the levels of savings and investment can have implications for the sustainability of the external position, for a given current account imbalance. High levels of investment imply -- ceteris paribus -- higher future growth through the build-up of a larger productive capacity, and therefore enhance intertemporal solvency (see equation (3)). $2 /$ High savings and investment ratios can also act as a signal of creditworthiness to international investors, because they raise the perceived ability to service and reduce external debt. 3 / However, since saving funds can be poorly allocated among investment projects in countries in which investment is centrally allocated and the capital markets are segmented, the investment-output ratio could be a poor indicator of sustainable current account deficits.

1/ See Stiglitz and Weiss (1981) and Milesi-Ferretti and Razin (1995). As can be seen from equation (9), a higher interest rate raises the probability of default even for a given project.

$\underline{2} /$ This assumes that investment projects are growth-enhancing. It is possible, however, that investment projects are not chosen efficiently, because of financial market distortions or because they are driven by political priorities.

3/ Higher investment would be reflected in a higher present value of output (a higher $Y$ ), reducing default risk, similar to the income term in Stiglitz and Weiss(1981). On the role of investment in a default-risk model, see also Aizenman(1992). 
ii) Economic growth. Fast-growing countries can sustain persistent current account deficits without increasing their external indebtedness relative to GDP, as can be seen, for cxample, from equations (5) and (6). In addition to the accumulation of physical capital through investment, stressed in the previous paragraph, high growth is driven by other factors such as the accumulation of human capital and increases in total factor productivity. Clearly these factors play an important role in determining the sustainability of external imbalances since they determine a country's ability to service its external obligations in the future.

iii) Openness. The degree of openness can be defined as the ratio of exports to GDP. In order to service and reduce external indebtedness, a country needs to rely on traded goods' production as a source of foreign exchange. Clearly, countries with a large exports sector can service external debts more easily, because debt service will absorb a lower fraction of their total export proceeds. In order to generate the foreign exchange necessary to service external debt in case of an interruption in capital flows, a country needs to engineer a resource shift towards the exports sector. This sectoral shift is likely to be more costly in a closed economy. Furthermore, since this shift cannot occur instantly, sharp import compression may become necessary, with adverse consequences on the domestic industries relying on "essential" imported inputs (Sachs (1985) and Sachs and Warner (1995)).

It should also be noted that an open economy has a lower incentive to default on external debt because the trade disruptions associated with debt default wculd be very costly. Consequently, sudden reversals of capital inflows will be less likely, since foreign investors will perceive the country -- ceteris paribus -- as less risky. 1 /

The commodity composition of trade is an important indicator of vulnerability. Fluctuations in commodity prices have a larger impact on the terms of trade for countries with a narrow export base, and those particularly dependent on raw materials for their imports. Terms of trade fluctuations can weaken the ability of the economy to sustain current account deficits. $2 /$

The sectoral composition of growth may be an additional indicator of potential external difficulties. In particular, low export growth could reflect an exchange rate misalignment, which may point to the need of a policy reversal. A related argument is that for a small open economy large

$\underline{1}$ / In terms of the model of Stiglitz and Weiss (1981), higher costs of default would be equivalent to a higher collateral, $C$.

2/ Ghosh and Ostry (1994) found support for the view that large current account deficits are more likely to be unsustainable in countries with a less diversified export base in the context of a model based on precautionary savings. Mendoza (1995) presents evidence that the volatility of terms of trade is associated with lower economic growth in a wide sample of countries. 
external trade can imply a more diversified input base for production, and hence higher productivity growth. A positive impact on productivity can also come from access to technology embodied in internationally traded goods. 1 /

\section{iv) Composition of external liabilities}

The composition of external liabilities may have an impact on the ability of a country to absorb smoothly a shock. In general terms, we can distinguish between "debt" and "equity" instruments. In principle, equity financing allows asset price adjustments to absorb at least part of negative shocks, so that part of the burden is borne by foreign equity investors. In contrast, in the case of foreign currency debt financing, the country bears most of the burden, provided it does not default. The structure of equity and debt liabilities is also important in order to evaluate a country's vulnerability to shocks. With regard to equity, portfolio investment is potentially more volatile than foreign direct investment. With regard to debt, its maturity structure, currency composition and interest rate structure (fixed or floating rate) all affect vulnerability to shocks. The risk of external shocks is enhanced by short-term maturities, foreign currency denomination and variable interest because the impact on the debt burden is magnified.

v) Financial structure. In developing countries, financial intermediation is typically dominated by banks: bank deposits are the most important form of private savings and bank loans the main source of finance for firms. $2 /$ The disciplinary effect of competition with alternative forms of financial intermediation is limited, and therefore the role of bank supervision is essential. The fact that it is more likely that banks will be bailed out by the central bank (government), relative to other financial institutions, can also imply more risk-taking behavior in a bank-dominated financial system. Problems are likely to surface when the central bank itself is involved in direct lending, financed through high reserve requirements, because of the conflict this implies with the arm's length supervision role. A financial structure with poor bank supervision, weak monitoring of borrowers make a country more vulnerable to external shocks, and more prone to experience balance of payments crises.

\section{V.2 Macroeconomic Policy Stance}

1/ For some empirical evidence on the importance of international productivity spillovers, see Coe and Helpman (1995) and Coe, Helpman and Hoffmaister (1995).

2/ For evidence on Latin American countries, see Rojas-Suarez and Weisbrod (1995). 
i) Monetary and exchange rate policy. The level of the real exchange rate is an important indicator of sustainability. A persistent real exchange rate appreciation can be driven by "fundamental" factors such as high productivity growth in the traded goods sector, or favorable terms of trade shocks. However, in the context of a fixed or managed exchange rate system, it could reflect a fundamental inconsistency between the monetary policy stance and exchange rate policy, giving rise to "overvaluation".

In this case, the overvaluation would typically be maintained by high domestic interest rates and/or by the presence of capital controls. An overvalued exchange rate would encourage a decline in savings as domestic residents intertemporally substitute present for future consumption. It can also cause a decline in economic activity, both because of the high interest rates needed to maintain the exchange rate peg and because the traded goods sector is "priced out" of world markets. These effects would contribute to a widening of current account imbalances and loss of foreign exchange reserves. The drain of foreign reserves can be reinforced by expectations of a future devaluation, that encourage capital outflows.1/ Finally, the weakening of the export sector hinders the ability of the country to sustain external imbalances.

A real exchange rate appreciation may also be caused by large capital inflows; to the extent that these are not driven by long-term fundamentals, they can result in an overvaluation. Weaknesses in domestic financial intermediation and supervision (which we discuss below) can hinder the efficient allocation of capital inflows between consumption and investment, and contribute to the overvaluation. 2 /

ii) Fiscal policy. In order to examine the relation between fiscal and external imbalances, we start from a benchmark "debt neutrality" case (Barro (1974)), where there is no correlation between the public sector deficit and current account imbalances. This can be seen most easily in the context of the intertemporal framework of Section III : the current account is independent of the time profile of taxation, and therefore of the budget deficit. $\underline{3}$ / Among other things, the debt neutrality result relies

1/ The link between inconsistent monetary and exchange rate policies and speculative attacks on a country's foreign exchange reserves was elegantly formalized by Krugman (1979).

$\underline{2} /$ On problems posed by large capital inflows, see, for example, Fernandez-Arias and Montiel (1995).

$\underline{3} /$ This result can be understood by considering the effect of public sector deficits (negative public savings) on private sector savings. If the private sector fully internalizes the fact that higher deficits today will need to be covered by higher taxation in the future, private savings will rise, to fully offset the negative public savings, without any interest rate change (and therefore without any effect on investment). In that case, government bonds issues associated with the deficit are not regarded as net wealth, and do not influence current private consumption. The invariance of the domestic savings/investment balance implies that the current account is unaffected. 
on the fact that consumption depends only on lifetime income and that taxes are not distortionary. Distortionary taxes would have an effect on the level of output and investment, and would therefore affect the current account. Furthermore, if consumption depends also on disposable incorne, for exarnple because some consumers are unable to borrow at the same terms as the government, lower taxes today would induce higher consumption (see Jappelli and Pagano (1989)). Similarly for the firms, the effective easing of borrowing constraints associated with lower present taxes could induce an increase in investment. Analogous effects would obtain if future tax obligations are not expected to fall entirely on current period taxpayers. 1 /

All the effects discussed so far would imply, among other things, a positive correlation between budget deficits and current account deficits. The discussion also suggests that the strength of this correlation may depend on the degree of development of domestic financial markets. Namely, in countries with underdeveloped or highly regulated financial markets we would expect to find stronger links between the fiscal stance and the current account balance, and therefore between government budget solvency and current account sustainability.

The degree of private sector saving offset to a given increase in public sector sảing may also depend on the level of public debt. With low public debt the current generation could view a future debt stabilization policy (via fiscal surpluses) as remote, thus the future tax liabilities are perceived to be small and fiscal adjustments affect aggregate demand and savings. In contrast, with high public debt the future debt stabilization looks imminent and the debt neutrality is at a full force. The link between the twin deficits may therefore be stronger the lower is the level of public debt. Another implication of this line of reasoning is that the effects of fiscal stabilization on aggregate demand are weaker the higher is the public debt burden.2/

1/ If the future tax obligations arising from the deficit are expected to be met by higher consumption taxes, present consumption would rise (and present savings would fall) as the increase in the relative price of future consumption induces intertemporal substitution of present for future consumption (see Frenkel and Razin (1987)). The same argument applies if future tax obligations are to be met with the inflation tax (for example, after the abandonment of an exchange rate peg). Indeed, if consumers have to hold money balances for consumption purposes, future inflation increases the relative cost of future consumption purchases (see, for example, Calvo (1986)), thereby encouraging a shift from future to present consumption. Differences between present and expected future tax burden can be the effect of political factors. Consider, for example, a model in the spirit of Alesina and Tabellini (1990), where there exists a politically motivated fiscal deficit bias, caused by the fact that the current government does not share the spending priorities of a possible successor, and is therefore willing to commit future tax revenues to debt service, rather than to spending. This will result in future tax rates being higher than current tax rates. If taxes fall on consumption, intertemporal substitution would push private agents towards higher consumption in the present than in the future, therefore implying a current account deficit.

2/ For an analytical presentation of this argument, see Sutherland (1995). 
iii) Trade policy. Countries with a protectionist trade policy are more likely to have a limited export base. As highlighted in our discussion of openness, they are more vulnerable to shocks and their current account deficits less sustainable. A process ố trade liberalization typically necessitates shifts in relative prices; under these circunıstances, a devaluation of the exchange rate would encourage a transfer of resources to the traded goods sector (see, for example, Edwards (1989)). It would also facilitate containment of external imbalances during the transition.

iii) Capital account policy regime. When the capital account is very open, de jure or de facto, a country is more vulnerable to sudden reversals in the direction of capital flows. This reversal may concern not only foreign capital, but also domestic capital.1/ Clearly, the degree of de facto opening of the capital account is endogenous, and depends in particular on the strength of the incentives to export capital (risk-adjusted rate of return differentials due to domestic policy misalignments, political instability etc.). Capital controls are a distortion that puts a wedge between rates of return on capital in the domestic economy and abroad. They can also affect the consistency of the macroeconomic policy stance: for example, capital controls can allow a government to temporarily pursue ari expansionary monetary policy with a fixed exchange rate, thereby weakening the current account. An open capital account can provide a disciplining device, since this policy inconsistency would result in the collapse of the peg.

A related argument is that an open capital account could serve as a signal of a country's commitment to the pursuit of "sustainable" policies, and thereby raise foreign investors' perception of the country's creditworthiness. This would contribute to reducing the cost of capital for the country and/or to increase the supply of foreign funds (see, for example, Bartolini and Drazen (1994)). On the other side, economic research and practical experience have also highlighted the potential dangers associated with poor financial supervision and a weak banking system when the capital account is open (see, for example, Diaz-Alejandro (1985)).

1/ This is exemplified by the experience of several Latin American countries (such as Argentina, Mexico, Peru, and Venezuela) in the run-up to the debt crisis (see, for example, Diaz Alejandro (1985) and Sachs (1985)). For those countries, the level of "official" foreign debt at the time of the debt crisis was much higher than the cumulative value of past current account imbalances, indicating that the accumulation of debt had financed not only excess of imports over exports, but also private capital outflows. 


\section{V.3 Political economy factors}

Numerous empirical studies have documented the detrimental macroeconomic effects of political instability. $1 /$ in the context of current account sustainability, political instability can be important for various reasons. Domestic and foreign investors become more susceptible to the risk of a sudden policy reversal -- for example, a government favoring free capital mobility may be replaced by one more prone to the imposition of capital controls or more prone to default. This makes the occurrence of capital outflows more likely. Political instability is often driven by distributional conflict, which can cause capital flight as a response to the fear of capital taxation (see, for example, Alesina and Tabellini (1989)). Indicators of this type of political instability are for example, the historical frequency of changes in government and/or attempted coups, and measures of industrial strife.

The political situation can affect the sustainability of external liabilities for different reasons. For example, a "weak" government may have difficulties in undertaking economic adjustment that may be needed in response to a shock, because of the difficulty inherent in gathering sufficient political support. Also, a government facing an election may be reluctant to implement adjustment measures for fear of jeopardizing its electoral chances. Indicators of this form of "policy rigidity" àre the degree of support of the government in Parliament, the party composition of government (coalition vs majority) and the timing of elections.

\section{V.4 Market expectations}

So far we have discussed economic, structural and political economy factors that may affect the sustainability of persistent current account imbalances. A key issue is, of course, whether it is possible to rely on a set of indicators that help signal the likelihood of a major policy shift and/or a crisis situation. As mentioned in Section II, private agents' behavior is affected by their anticipation of possible future policy shifts. The behavior of capital flows and foreign exchange reserves are the most obvious indicator of domestic and foreign investors' perceptions of a country's creditworthiness. Bond prices or interest rate spreads on international loans and bonds (such as Brady bonds) also provide a useful measure of international investors' perceptions of the country's ability to service its external obligations. There is a danger, however, that these market-based indicators would fail to signal

\footnotetext{
1/ See, for example, Alesina, Ozler, Roubini and Swagel (1992) and Cukierman, Edwards and Tabellini (1992).
} 
problems ahead of time; $\underline{1} /$ it is therefore essential to take into consideration the more general set of factors discussed earlier in this section.

\section{COUNTRY EPISODES AND POLICY LESSONS}

So far we have discussed conceptual aspects of current account sustainability, emphasizing the role of overall foreign indebtedness, vulnerability to shocks and government solvency. We now turn to a stylized analysis of the experience of a selected group of countries with persistent current account imbalances. These experiences are divided into "good" and "bad" ones. We define "good" experiences as those where crises did not occur, either because of a fundamental consistency in economic policy or because of a timely policy reversal. By contrast, we define "bad" experiences as those in which a crisis did occur, so that a policy reversal was forced by the crisis. We attempt to characterize these different experiences in terms of the factors discussed in the previous section: macroeconomic policy stance; structural characteristics of the economy; political factors; and balance of payments shocks.

The countries we consider in this paper are Australia, Chile, Ireland, Israel, Mexico, and South Korea. The experiences of these countries can be broadly characterized as follows. Chile (1982) and Mexico (1976, 1982 and 1994) suffered external crises. Other countries, such as Ireland (1982 and 1987), Israel (1985) and South Korea (1980) had a policy reversal that prevented potential external crises, while Australia (1990-95) has sustained persistent current account deficits with no drastic policy change. We shall look for common factors in the above experiences in order to draw some tentative policy lessons. In order to do so, we present a set of Charts and a Table highlighting stylized characteristics of these country episodes.

The main lesson that we draw from these episodes is that it is necessary to consider a combination of factors, rather than single variables, in order to gauge the likelihood that persistent imbalances will be sustainable. Table 1 provides a set of sustainability indicators for the various country episodes.

A first factor, directly related to solvency, is the implied resource transfer needed to prevent the external debt to output ratio from rising. This resource transfer is equal to the debt service ratio, adjusted for growth and real exchange rate changes (equation (3)). In the crisis episodes we examined, this measure of the external burden was indeed high with respect to the other episodes.

1/ This may reflect the possibility that financial markets react too late or too abruptly, or that they are plagued by misperceptions and expectational errors, making them less reliable in ascertaining sustainability. 
A second factor which seems to play an important role is the ratio of exports to GDP. Countries that successfully adjusted after experiencing large current account imbalances, such as Korea, Ireland and Israel, had a large export share. By contrast, the export to GDP ratio was iower in Mexico (especially in 1982) and in Chile, although it should be pointed out that exports were rising rapidly prior to all three crisis episodes considered (Mexico II and III; Chile). $1 /$ This finding is in line with results presented in Sachs (1985), who compares East Asian and Latin American countries at the time of the debt crisis. It is also theoretically plausible -- the shift in resources needed to achieve sustained trade surpluses is easier in countries with a large traded goods sector, and the vulnerability to trade disruptions in case of default is larger.

A third factor is the real exchange rate. The three crisis episodes we consider are all charactericed by an appreciated real exchange rate (with respect to historical averages) in the period leading up to the crisis. The appreciation was accompanied by very rapid growth of imports. It is interesting to note that an exchange rate devaluation was undertaken by all countries under consideration -- for some it was forced by events, while for others it was preventive.

A fourth factor is the savings ratio, which was very low (and declining) in Mexico 1994 and, especially, in Chile in the run-up to the crisis. Savings were also low in Ireland and Israel, but the export ratios were considerably higher. Economic theory suggests that, for a given current account deficit, high savings are an indicator of intertemporal solvency and, therefore, creditworthiness, because (for a given current account deficit) they imply high investment and therefore an enhanced capacity to rcpay debt in the future. Furthermore, the necessary adjustment during a crisis does not require to reduce investment to very low levels. It is interesting to observe that, in both Chile and Mexico III the low savings rates were not attributable to public sector imbalances, but rather to high private sector consumption. In both Ireland and Israel the low savings rates reflected large public sector imbalances; these experienced a dramatic turnaround as a result of the adjustment process. In Korea the savings rate was higher than in the other countries we consider. Finally, in Australia the savings rate is low with respect to other countries in our sample. It should be noted, however, that when domestic capital markets are segmented and bank supervision is weak, the allocation of capital among investment projects can be inefficient and risk-taking excessive. In this case, the level of investment (and savings) can be a weak predictor of sustainability. As highlighted in Table I, the investment ratio has been higher in Mexico II and III compared to Ireland and Australia A fifth factor, the fiscal policy stance,

1/ It is interesting to point out that Chile's successful recovery after the crisis was characterized by a rapid increase in the export ratio. 
does not seem to play a defining role that would allow us to systematically signal crisis episodes ahead of time. In Chile and in Mexico III the current account deficits prior to the crisis were not associated with large fiscal imbalarices, while they were in Mexico II. It is inportant to point out, however, two aspects. First, the crises entailed, ex-post, a large fiscal cost for the government in the form of bailouts of banks and firms, as well as the shouldering by the budget of private external debt. Second, among our "good" episodes, the turnaround in external accounts in Israel and Ireland came as a result of a policy shift in which fiscal consolidation played a major role.

A sixth factor is the degree of political instability or uncertainty. This played a role in all three Mexican external crises: 1976, 1982 and 1994 were all electoral years in Mexico. In all these cases, signs of a possible crisis were already surfacing, but the imminence of an election made the government reluctant to undertake severe adjustment measures. In Korea, the 1980 recession was probably accentuated by the difficult political situation following the assassination of President Park; in Israel 1984 was an election year, and the economic policy stance was considerably loose, leading to a larger fiscal deficit and further acceleration of inflation. The successful adjustment in 1985 was undertaken by a "national unity" government. In Ireland, the fiscal adjustment in 1982 was made more difficult by instability in the governing coalition. Interestingly, the successful adjustment of $198 /$ was undertaken by a minority government, albeit with general political support. In Chile, political instability did not play a role.

A seventh factor is the composition of capital inflows. Australia has relied more heavily on equity than the developing countries we have examined, and Ireland has received substantial inflows of foreign direct investment. This implies that the risk of domestic and external shocks is shared between foreign investors and the country, reducing the vulnerability of the external position. Furthermore, in countries such as Ireland and Australia, that have a more developed bond market, a significant fraction of external debt is denominated in domestic currency, making them less vulnerable to a real exchange rate changes. Another aspect of foreign currency debt obligations that has played an important role is the determination of the interest rate. At the time of the debt crisis, most of the external debt in Mexico and Chile (but not in Korea) was at a floating interest rate, making the external position more vulnerable to interest rate shocks.

Finally, an eighth factor is the quality of financial intermediation and especially the fragility of the banking system. This factor played an important role in all the crises we have considered, and made the adjustment process more painful. Weaknesses in banking system supervision, distortions in the incentive structure of banks, and lack of competition within the banking sector and from nonbank financial institutions imply inefficiencies in the intermediation of external funds associated with large 
current account deficits. For a given size of current account imbalances, these inefficiencies make the economy more vulnerable to changes in foreign investors' sentiment or other shocks.

\section{CONCLUDING REMARKS}

Persistent current account imbalances are often viewed as a sign of weakness, implying a need for policy action. Economic theory suggests, however, that intertemporal borrowing and lending are a natural vehicle to achieve faster capital accumulation, a more efficient allocation of investment, and the smoothing of consumption. In this paper we have considered to what degree persistent current account imbalances can be taken as a signal of a potential "hard lending", or crisis ahead. We have argued that traditional sustainability measures, based only on the notion of intertemporal solvency, may not be always appropriate, because they sidestep the issue of a country's willingness to repay its external obligations and the related issue of foreign investors' willingness to continue lending on current terms. We have therefore proposed an alternative notion of sustainability that emphasizes these two issues, in addition to pure solvency.

We have considered a list of operational indicators that can help shed light on the sustainability of external imbalances. In the light of these considerations, we have examined the experiences of a number of countries that ran persistent current account imbalances, some of which experienced an external crisis. A formal econometric analysis, while desirable, is difficult at this stage because of the number and nature of the episodes and the indicators being considered. We have nonetheless distilled from the case studies a number of stylized facts that could help evaluate the sustainability of external imbalances.

We conclude that a specific threshold on persistent current account deficits (such as $\mathbf{5}$ percent of GDP for 3-4 years) is not per se a sufficiently informative indicator of sustainability. The size of current account imbalances should be considered in conjunction with exchange rate policy and structural factors, such as the level and composition of external liabilities, the degree of openness and the composition of trade, the level of savings and investment. Persistent current account deficits should flash a red light if the export sector is small, debt service is large, savings are low, the financial sector is dominated by banks under weak supervision, and equity financing is small. 
References

Aizenman, Joshua (1992), "Trade Reforms, Credibility, and Development," Journal of Development Economics, 39:163-187.

Alesina, Alberto, Sule Ozler, Nouriel Roubini and Phillip Swagel (1992), "Political Instability and Growth", Journal of Economic Growth, forthcoming.

Alesina, Alberto and Guido Tabellini (1989), "External Debt, Capital Flight and Political Risk,", Journal of International Economics 27, 199-220.

Alesina, Alberto an Guido Tabellini (1990), "A Positive Theory of Fiscal Deficits and Government Debt in a Democracy", Review of Economic Studies 57, July, 403-14.

Barro, Robert J. (1974), "Are Government Bonds Net Wealth?", Journal of Political Economy 82, November/December, 1095-1117.

Bartolini, Leonardo and Allan Drazen (1994), "Capital Controls as a Signal", mimeo, International Monetary Fund and University of Maryland.

Calvo, Guillermo A. (1986), "Temporary Stabilization: Predetermined Exchange Rates," Journal of Political Economy 94, 1319-29.

Calvo, Gui:'lermo A. (1995), "Varieties of Capital Market Crises,", mimeo, University of Maryland.

Calvo, Guillermo A. and Enrique G. Mendoza (1995), "Reflections on Mexico's Balance-of-Payments Crisis:

A Chronicle of a Death Foretold," mimeo, University of Maryland and Federal Reserve Board, August.

Coe, David and Elhanan Helpman (1995), "International R\&D Spillovers", European Economic Review 39, May, 859-87.

Coe, David, Elhanan Helpman and Alex Hoffmaister (1994), "North-South R\&D Spillovers", IMF Working Paper no. 94/144, December.

Cohen, Daniel (1995), "The Sustainability of African Debt", mimeo, CEPREMAP, September.

Corsetti, Giancarlo and Nouriel Roubini (1991), "Fiscal Deficits, Public Debt and Government Solvency: Evidence from OECD Countries", Journal of the Japanese and International Economies 5, 354-80.

Cukierman, Alex, Sebastian Edwards and Guido Tabellini, "Seigniorage and Political Instability", American Economic Review 82, June, 537-55.

Diaz-Alejandro, Carlos F. (1985), "Goodbye Financial Repression, Hello Financial Crash", Journal of Development Economics 19, 1-24.

Edwards, Sebastian (1989), Real Exchange Rates, Devaluation and Adjustment, Cambridge, Mass.: MIT Press. 
Fernández-Arias, Eduardo and Peter Montiel (1995), "The Surge in Capital Inflows to Developing Countries: an Analytical Overview", mimeo, The World Bank, August.

Frenkel, jacob and Assaf Razin (1987), Fiscal Policy in the World Economy, Cambridge, Mass.: MIT Press.Second Edition, 1994; New Edition, forthcoming 1996.

Gale, David (1973), "Pure Exchange Equilibrium of Dynamic Models," Journal of Economic Theory 6, 12 36.

Glick, Reuven and Kenneth Rogoff (1995), "Global versus Country-Specific Productivity Shocks and the Current Account", Journal of Monetary Economics, April.

Ghosh, Atish R. and Jonathan D. Ostry (1994), "Export Instability and the External Balance in Developing Countries", IMF Staff Papers 41 no. 2, June, 214-35.

Ghosh, Atish R. and Jonathan D. Ostry (1995), "The Current Account in Developing Countries: a Perspective from the Consumption Smoothing Anproach ', The World Bank Economic Review 9 no. 2, 305-33.

Horne, Jocelyn (1991), "Criteria of External Sustainability", European Economic Review 35, 1559-74.

Jappelli, Tullio and Marco Pagano (1994), "Savings, Growth, and Liquidity Constraints", Quarterly Journal of Economics CIX, February, 83-109.

Krugman, Paul (1979), "A Model of Balance-of Payments Crises," Journal of Money Credit and Banking, 11 : 312-325.

Krugman, Paul (1985), "Is the Strong Dollar Sustainable", in The US Dollar -- Recent Developments, Outlook and Policy Options, Federal Reserve Bank of Kansas City.

Leiderman, Leonardo and Assaf Razin (1991), "Determinants of External Imbalances: The Role of Taxes, Government Spending, and Productivity," Journal of the Japanese and International Economies 5, 42150.

Milesi-Ferretti, Gian Maria and Assaf Razin (1995), "Current Account Sustainability", mimeo, International Monetary Fund, December.

Obstfeld, Maurice and Kenneth Rogoff (1995), "Foundations of International Macroeconomics", mimeo, University of California, Berkeley and Princeton University.

Razin, Assaf (1995), "The Dynamic-Optimizing Approach to the Current Account: Theory and Evidence", in Understanding Interdependence: The Macroeconomics of the Open Economy, edited by Peter B. Kenen, Princeton, NJ: Princeton University Press.

Rojas-Suarez, Liliana and Steven Weisbrod (1995), "Financial Fragilities in Latin America: the 1980s and the 1990s", IMF Occasional Paper no. 132, October. 
Sachs, Jeffrey (1985), "External Debt and Macroeconomic Performance in Latin America and East Asia", Brookings Papers on Economic Activity 1, 523-64.

Sachs, Jeffrey and Andrew Warrer (1995), "Economic Reforın and the Process of Global Integration", Brookings Papers on Economic Activity 1, 1-95.

Stiglitz, Joseph and Andrew Weiss (1981), "Credit Rationing in Models with Imperfect Information", American Economic Review 71, June, 393-410.

Sutherland, Alan (1995), "Fiscal Crises and Demand: Can High Public Debt Reverse the Effects of Fiscal Policy?", CEPR Discussion Paper no. 1246, September. 
$-24-$

Table 1: Sustainability Indicators

\begin{tabular}{|c|c|c|c|c|c|c|c|c|}
\hline & $\begin{array}{c}\text { Australia } \\
1990-94\end{array}$ & & $\begin{array}{c}\text { Chile } \\
1979-81 \\
(1982-83)\end{array}$ & $\begin{array}{l}\text { Ireland } \\
1979-86 \\
(1987-90)\end{array}$ & $\begin{array}{l}\text { Israel } \\
1982-84 \\
(1985-86)\end{array}$ & $\begin{array}{c}\text { Korea } \\
1977-82 \\
(1983-88)\end{array}$ & $\begin{array}{c}\text { Mexico II } \\
1977-81 \\
(1982-83)\end{array}$ & $\begin{array}{l}\text { Mexico III } \\
1991-94 \\
(1995)\end{array}$ \\
\hline CA Balance* & -4.9 & -7.7 & $(-7.6)$ & $-8.5(-0.6)$ & $-7.0(3.0)$ & $-5.4(2.6)$ & $-5.0(0.2)$ & $-7.1(-1.0)$ \\
\hline Savings* & 18.3 & 9.3 & $(5.8)$ & $16.0(15.7)$ & $15.0(21.0)$ & $25.6(31.6)$ & $18.7(22.0)$ & 14.0 \\
\hline Inves tment* & 23.2 & 17.0 & $(13.5)$ & $24.5(16.3)$ & $22.0(18.0)$ & $31.0(29.0)$ & $23.7(21.8)$ & 21.0 \\
\hline Exports* & 17.0 & 20.7 & $(21.7)$ & $52.4(60.0)$ & $33.0(34.0)$ & $32.5(36.9)$ & $10.6(17.2)$ & $16.5(20.0)$ \\
\hline Debt/GDP** & 36.0 & 50.0 & $(78.0)$ & $58.4(40.9)$ & $46.0(45.0)$ & $52.3(14.8)$ & $32.6(66.6)$ & $35.5(39.0)$ \\
\hline $\begin{array}{l}\text { Debt Service } \\
\text { Burden }\end{array}$ & 2.1 & 6.0 & $(11.0)$ & $-\cdots$ & $4.0(4.0)$ & $5.8(1.7)$ & $4.1(7.0)$ & 2.2 \\
\hline $\begin{array}{l}\text { Fiscal } \\
\text { Balance }\end{array}$ & -2.2 & 2.1 & $(-3.3)$ & $-11.8(3.5)$ & $-13.0(2.0)$ & $-2.8(0.0)$ & $-8.0(-18.0)$ & $0.7(0.5)$ \\
\hline $\begin{array}{l}\text { Real Exchange } \\
\text { Rate* } 1 /\end{array}$ & 81.0 & 108 & 8.0 & 92.0 & 103.5 & 103.5 & 122.0 & $113.0(90)$ \\
\hline Growth & 3.0 & 7.9 & $(-7.4)$ & $2.8(56.7)$ & $2.0(4.0)$ & $5.8(10.7)$ & $7.5(-2.4)$ & 2.6 \\
\hline $\begin{array}{l}\text { Polit. } \\
\text { Uncertainty }\end{array}$ & no & no & & moderate & Post-election & yes & yes (election) & yes (election) \\
\hline $\begin{array}{l}\text { Financial } \\
\text { Structure }\end{array}$ & strong & wea & & strong & fair & fair & very weak & weak \\
\hline
\end{tabular}

* Average level during the three years preceding the crisis or policy shift.

** Year preceding the crisis (crisis year)

1) 100 is the historical mean. 


\section{Chart . Australia}
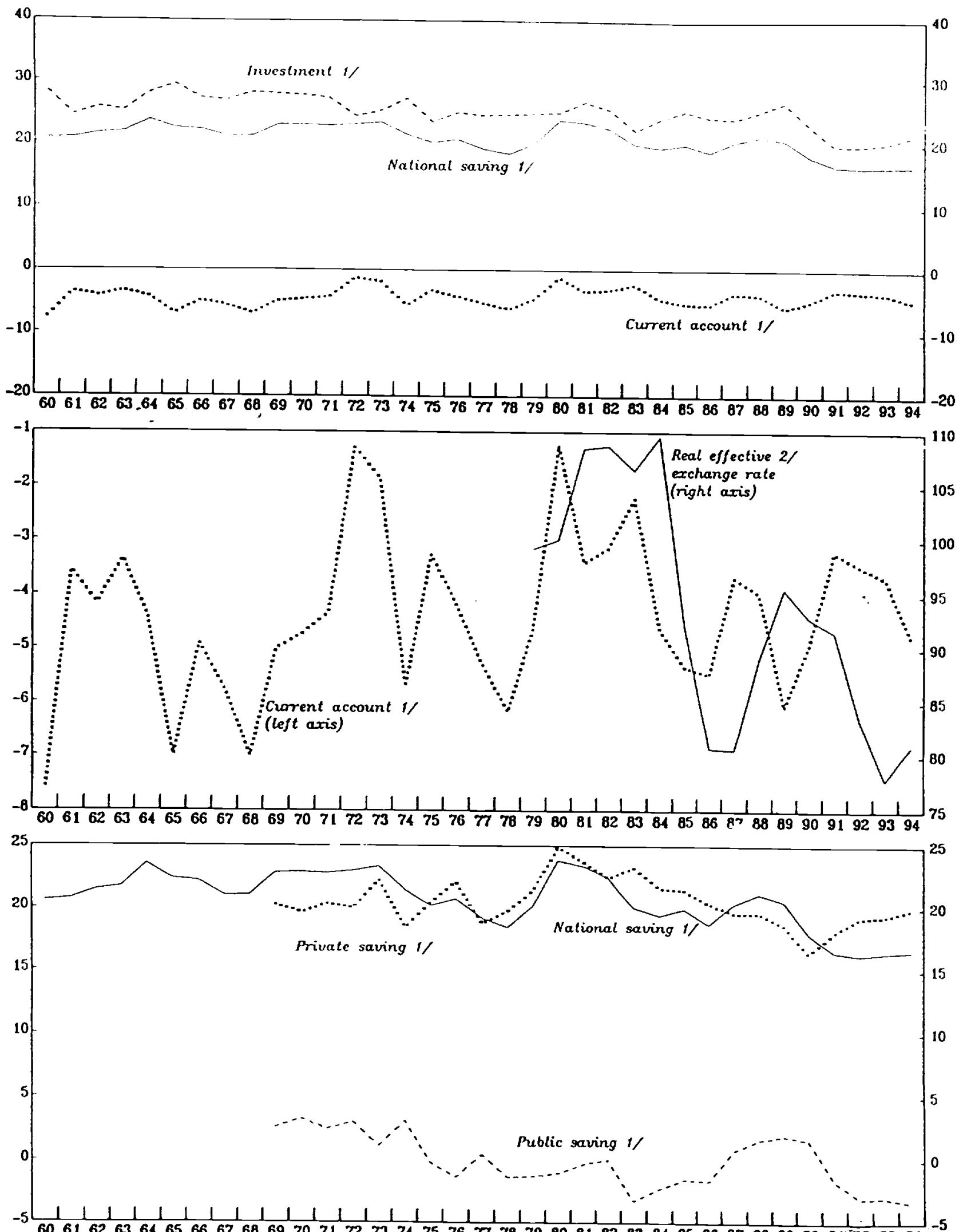

$60616263646566 \quad 67686970717273747576777879808182838485868788899091929394$ Sources: ING World Economic Outlook and Information Notioe, System.

1/ Ratio to GDP.

2) Index, 1980=100; based on consumer prices. 


\section{Chart . Chile}
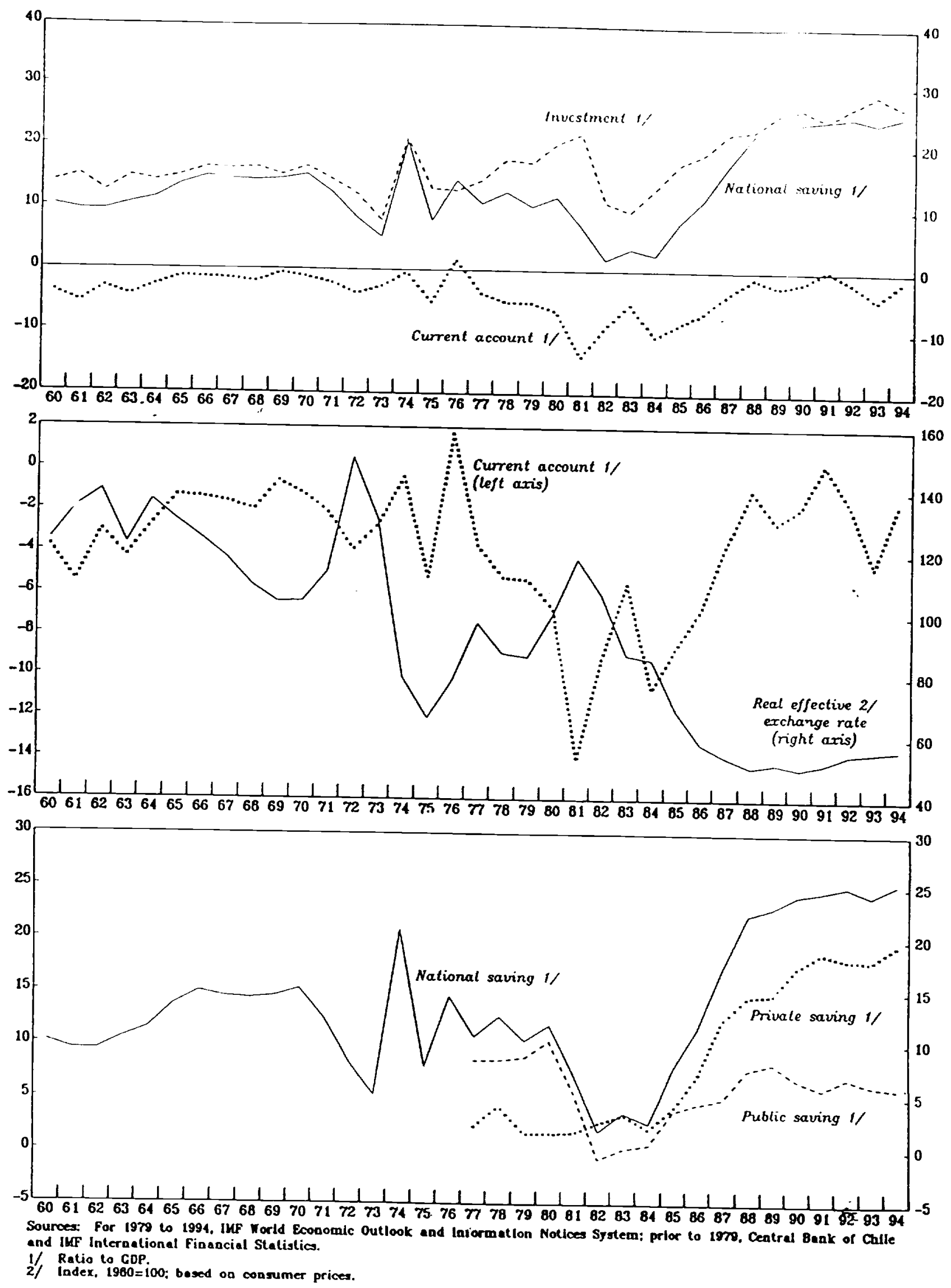


\section{Chart . Ireland}
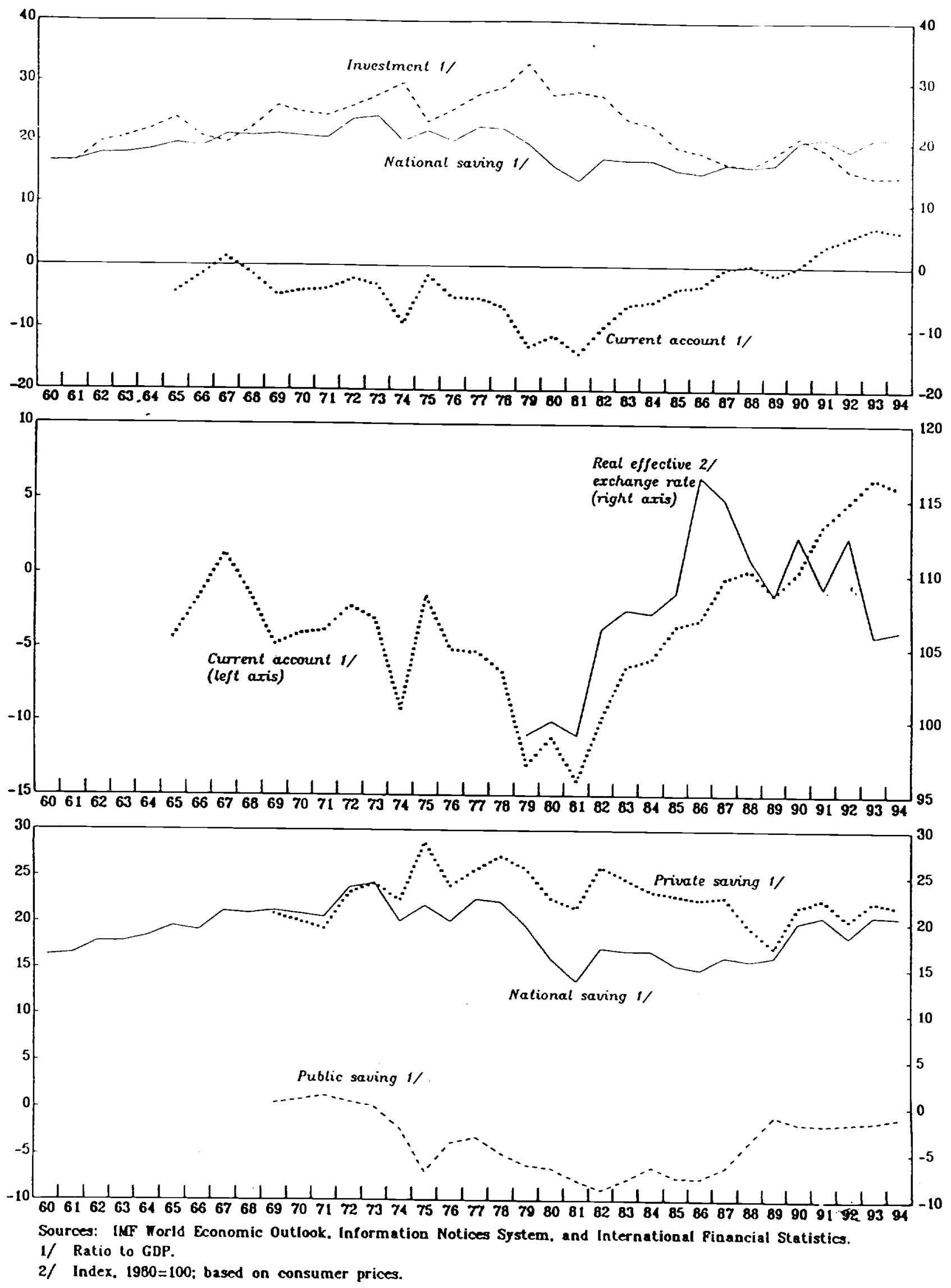


\section{Chart - Israel}
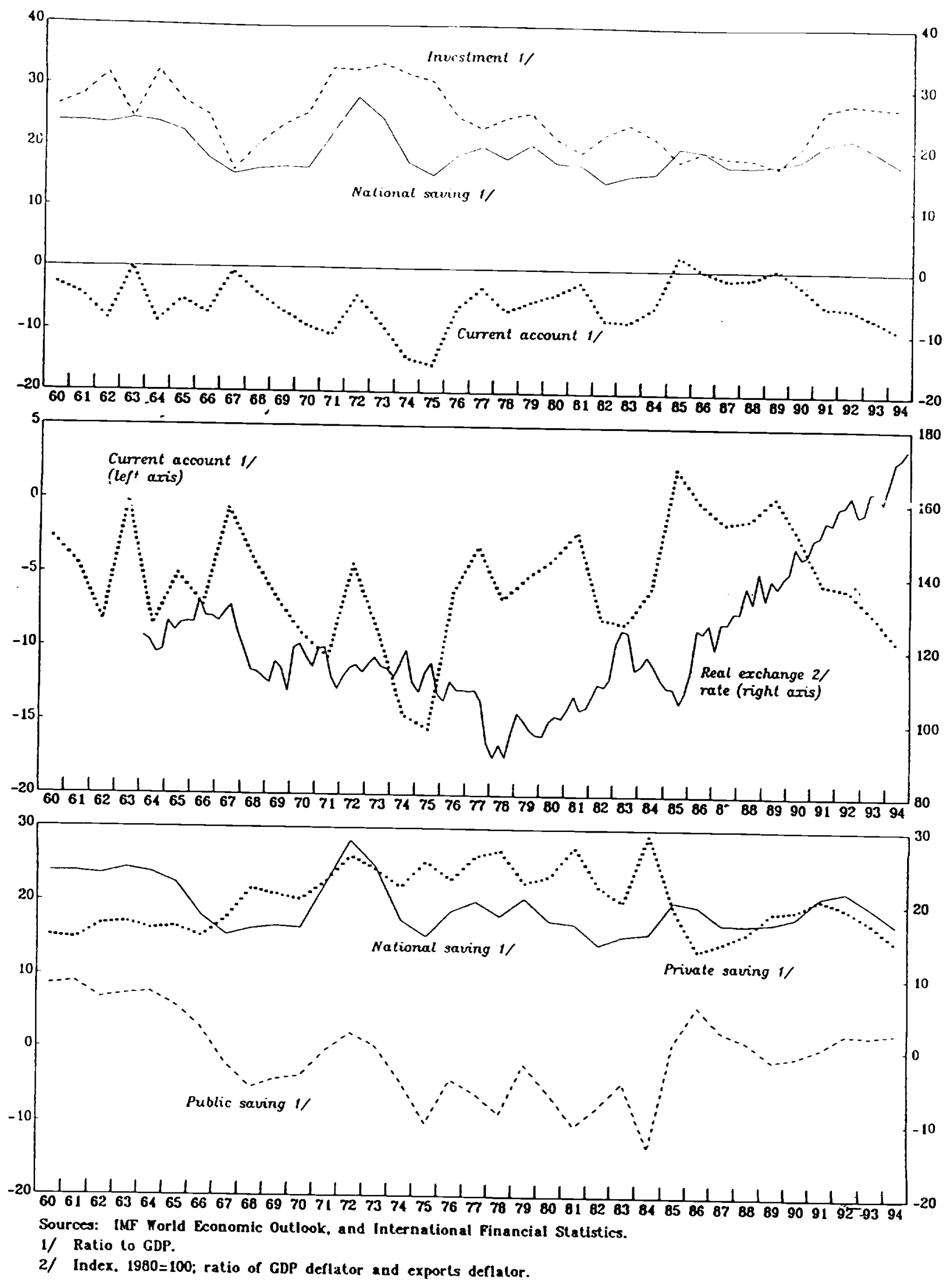


\section{Chart . Mexico}

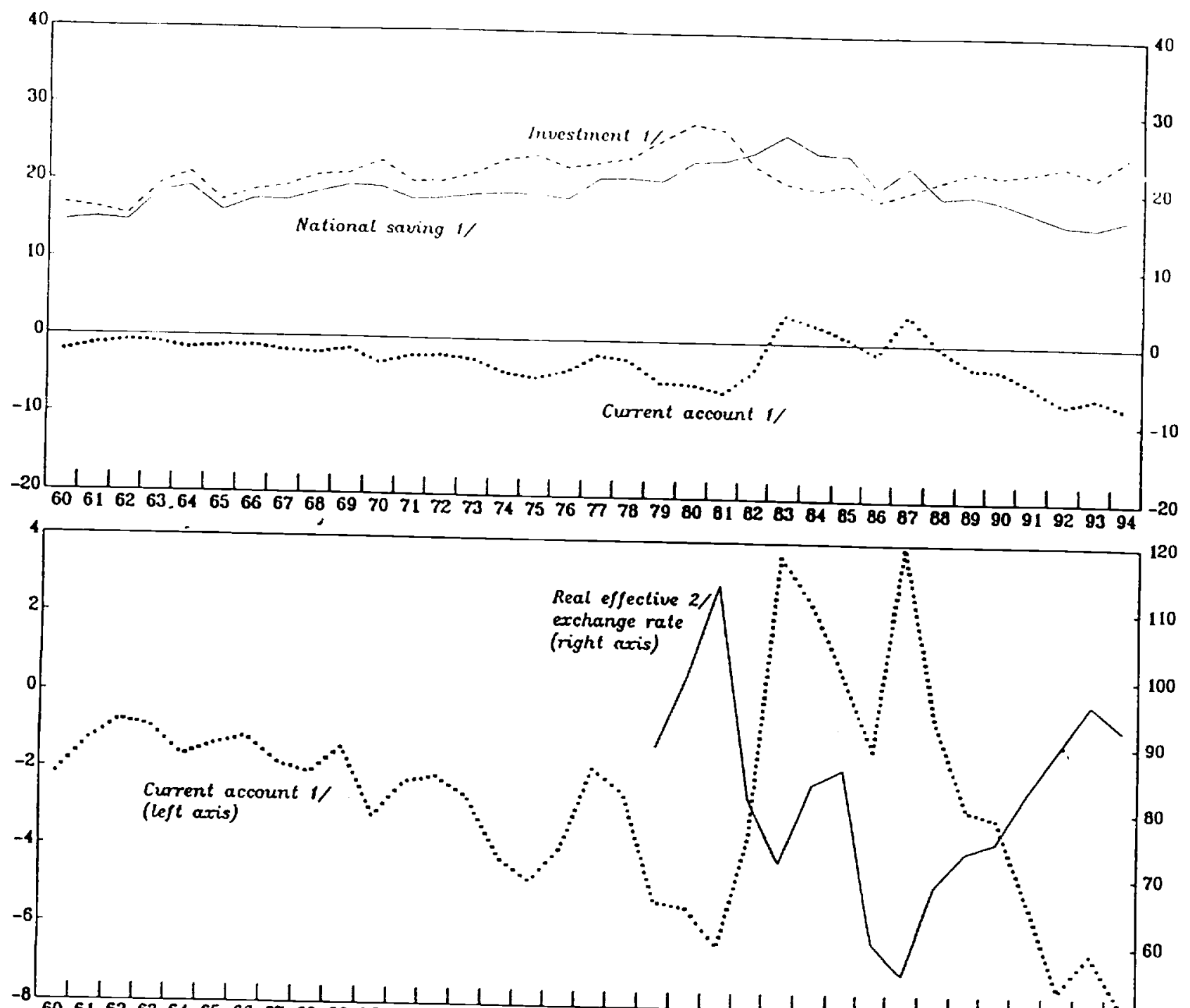

6061626364656667686970717273747576777879808182838485868786899091929394

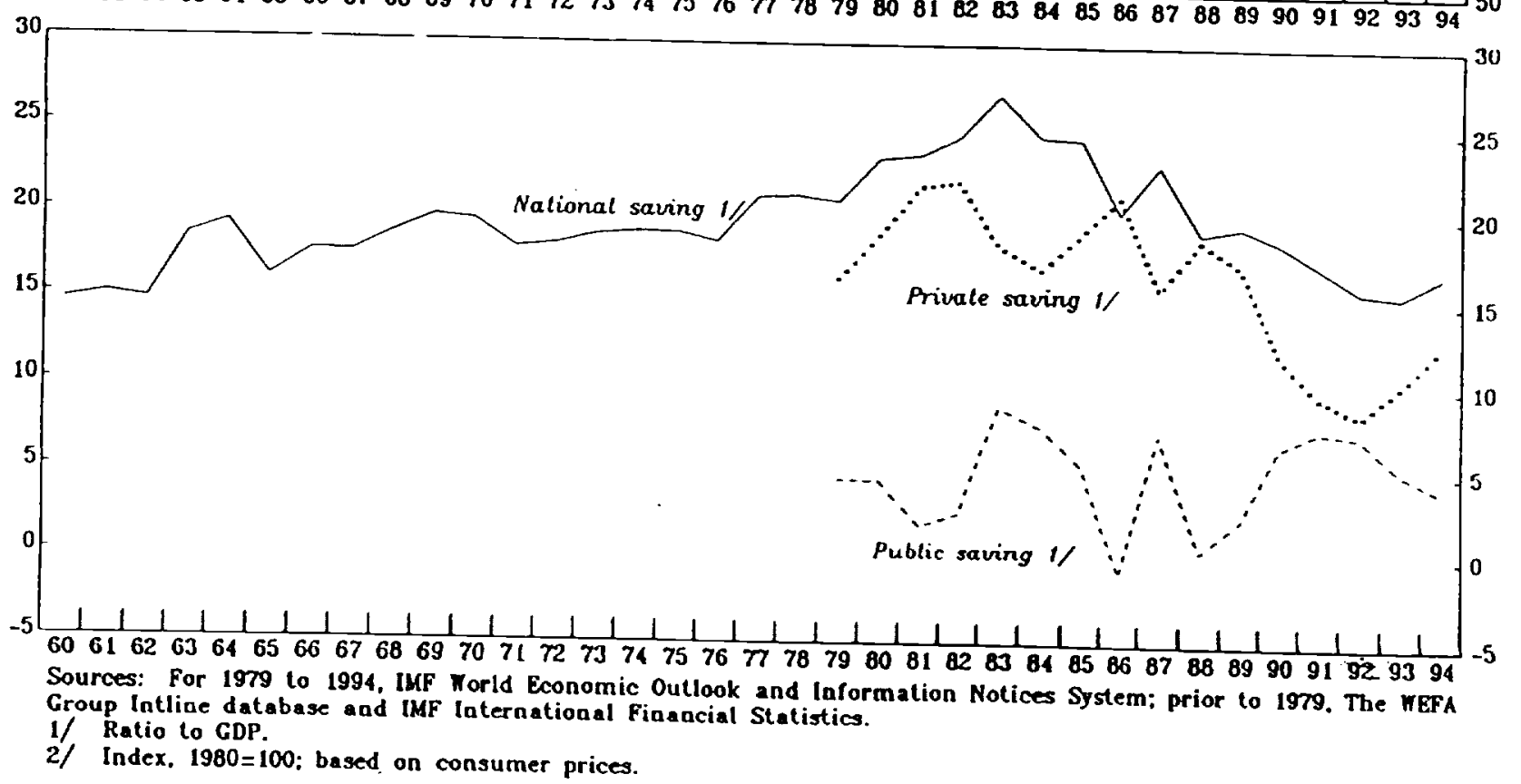




\section{Chart . Korea}
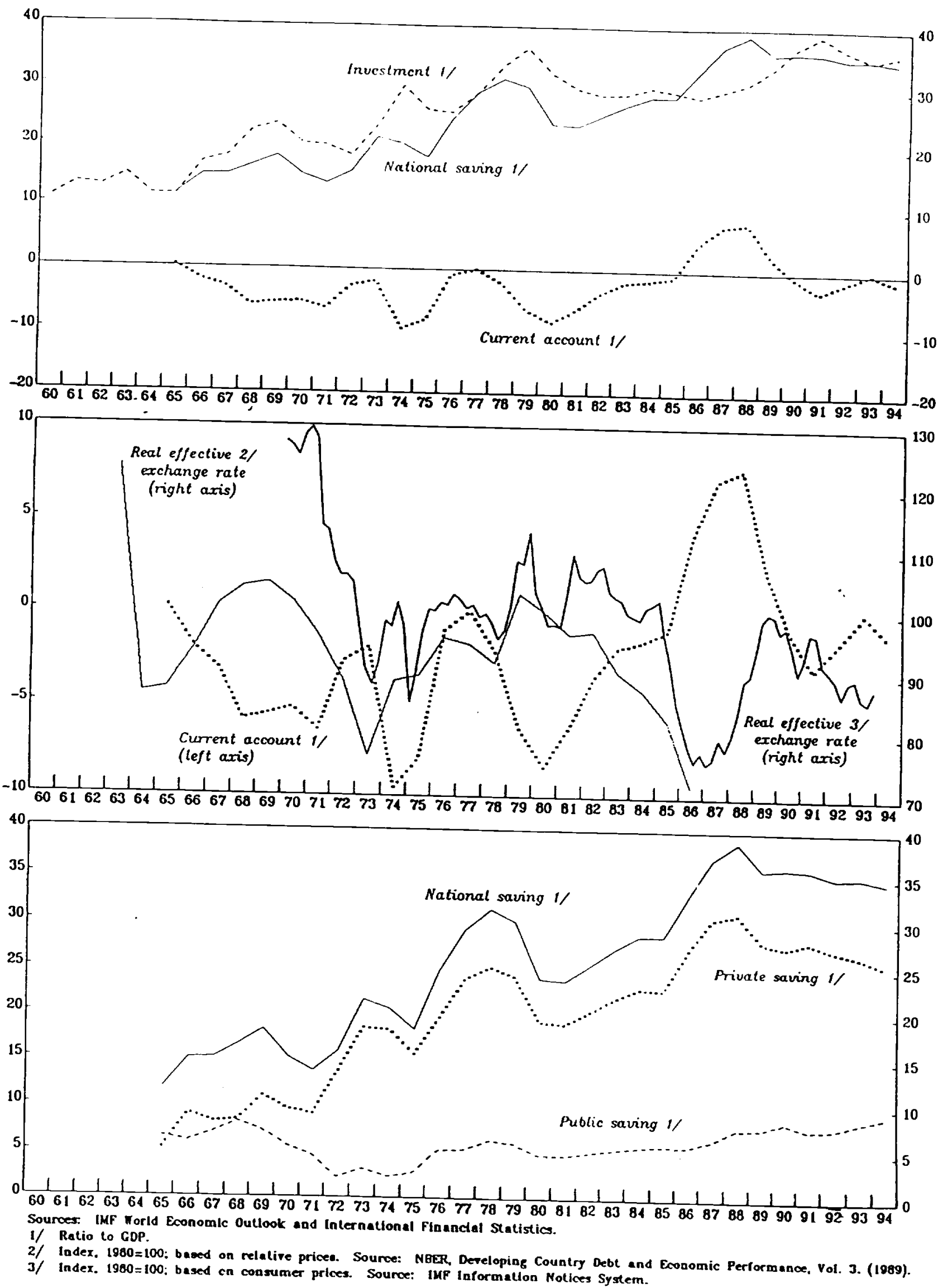


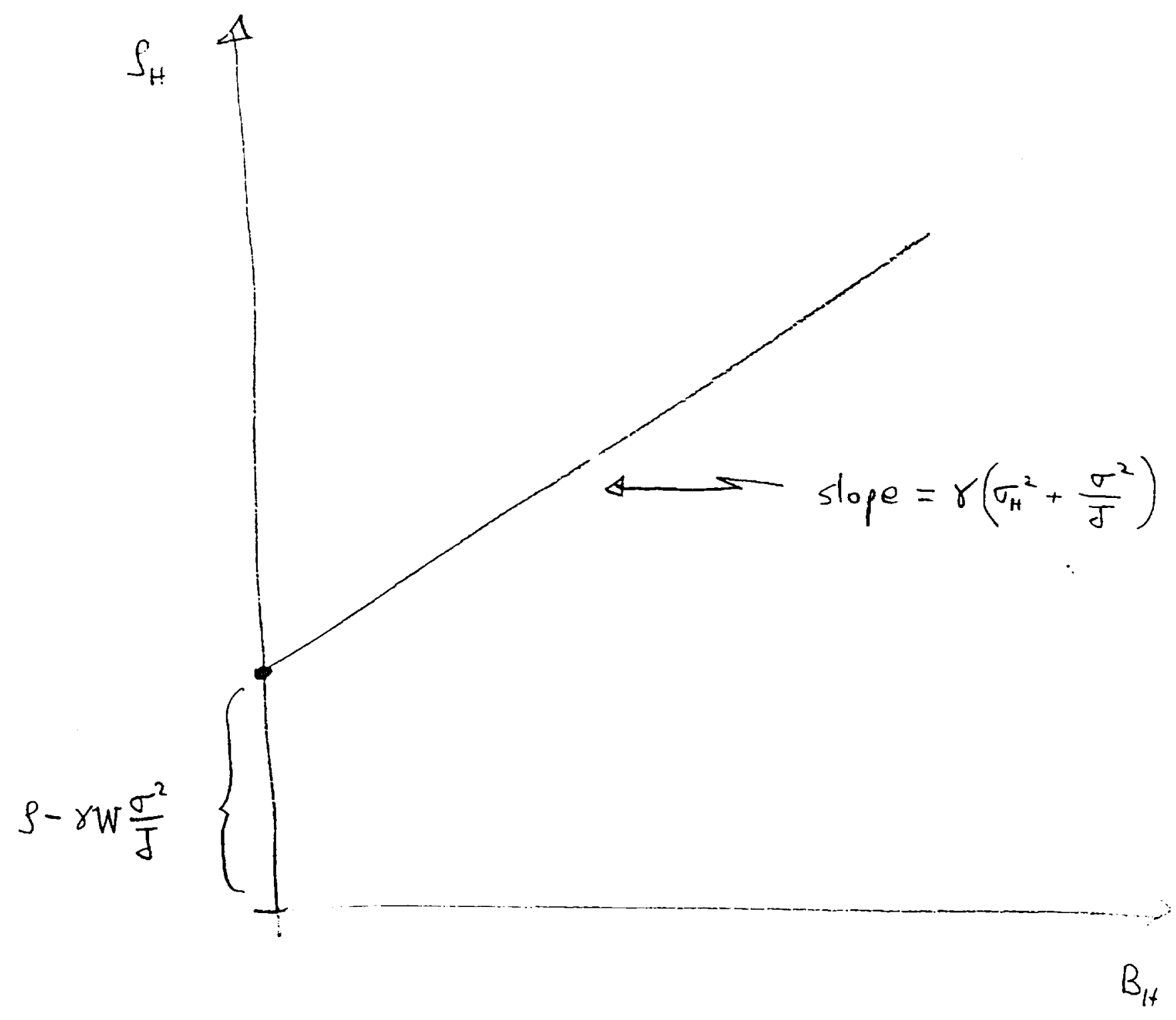

Figure 17.1 : Supply of External Funds 